ECOLOGICA, Vol. 28, No 101 (2021), 29-35

https://doi.org/10.18485/ecologica.2021.28.101.6

Originalni naučni rad

UDC:502:539.16(497.11)

\title{
Monitoring radioaktivnosti u Srbiji
}

\section{Monitoring radioactivity in Serbia}

\author{
Olivera Jovanović1, Zorica Baroš², Ana Marković3 \\ 1,2,3Visoka škola strukovnih studija - Beogradska politehnika, Beograd, Srbija \\ $1,2,3$ College of Vocational Studies - Belgrade Polytechnic, Belgrade, Serbia
}

Rad primljen: 14.11.2020, Rad prihvaćen: 19.02.2021.

Sažetak: Sistematsko ispitivanje radioaktivnosti u životnoj sredini se prema Zakonu od zaštiti od jonizujućeg zračenja i o nuklearnoj sigurnosti vrši radi utvrđivanja prisustva radionuklida u životnoj sredini i procene nivoa izlaganja stanovništva jonizujućim zračenjima i to u redovnim uslovima, u slučaju sumnje na akcident i toku akcidenta. Sakupljanje i analizu uzoraka obavljaju pravna lica čija je delatnost zaštita od zračenja, a ovlašćena su od strane Agencije za zaštitu od jonizujućih zračenja i nuklearnu sigurnost Srbije. U cilju dobijanja pouzdanih podataka vrše se sledeće analize: sadržaj radionuklida u vazduhu, sadržaj radoinuklida u čvrstim i tečnim padavinama, sadržaj radionuklida u površinskim vodama i rečnom sedimentu, sadržaj radionuklida u vodi za piće, sadržaj radionuklida u životnim namirnicama i stočnoj hrani i nivo izlaganja jonizujućem zračenju prirodnog porekla u boravišnim prostorijama i radnoj sredini. Što se tiče stanja kontaminacije radionuklidima u Republici Srbiji, neophodno je istaći da se u životnoj sredini detektuje određena količina radionuklida, ali da naša zemlja ne pripada kategoriji kritičnog stanja kada je jonizujuće zračenje u pitanju. Na osnovu detaljnih podataka institucija koje se bave monitoringom radioaktivnosti biće izneti podaci o stanju jonizujućeg zračenja u Republici Srbiji na osnovu merenja obavljenih u 2017. g.

Ključne reči: radionuklidi, jonizujuće zračenje, kontaminacija, monitoring radioaktivnosti.

\begin{abstract}
According to the Law on ionizing radiation protection and nuclear safety, the systematic research of radioactivity in the environment is conducted to determine whether radionuclides are present in the environment and to assess the level of exposure of the population to ionizing radiation in regular circumstances, in case of a suspected accident or during an accident. The collection and analysis of samples is performed by businesses engaged in radiation protection activities, authorized by the Agency for ionizing radiation protection and nuclear safety of Serbia. In order to receive reliable data, the following analyses are conducted: the amount of radionuclides in the air, the amount of radionuclides in solid and liquid forms of precipitation, the amount of radionuclides in surface waters and river sediments, the amount of radionuclides in drinking water, the amount of radionuclides in foodstuffs and fodder and the level of exposure to natural sources of ionizing radiation in living quarters and work spaces. When it comes to the state of contamination with radionuclides in the Republic of Serbia, it is necessary to point out that there is a certain amount of radionuclides detected in the environment, but that Serbia does not belong in the category of critical conditions when it comes to ionizing radiation. Based on detailed information from institutions engaged in monitoring radioactivity, data on the state of ionizing radiation in the Republic of Serbia based on measurements published in 2017 shall be presented.
\end{abstract}

Keywords: radionuclides, ionizing radiation, contamination, monitoring radioactivity.

\footnotetext{
1orcid.org/0000-0003-4459-0236, e-mail: ojovanovic@politehnika.edu.rs

2orcid.org/0000-0001-6927-4972, e-mail: zbaros@politehnika.edu.rs

${ }^{3}$ orcid.org/0000-0002-6750-7290, e-mail: andjelijica@hotmail.com
} 


\section{UVOD / INTRODUCTION}

Sagledavanje problematike životne sredine i rešavanje brojnih problema u ovoj oblasti podrazumeva angažovanje naučnika, studenta, đaka, građana, volontera, pojedinaca, koji bi svojim radom doprineli poboljšanju kvaliteta života, s obzirom na sve veće zagađenje životne sredine. Neki od problema koji se mogu rešavati jeste zamena fosilnih goriva obnovljivim izvorima energije, korišćenjem potencijala sunčeve energije, enegije vetra i geotermalnih izvora (Jovanović i dr., 2012a; Jovanović i dr., 2013a; Brkić i dr., 2012; Jovanović i dr., 2013b).

Veliki problem predstavlja opasnost od hemijskih akcidenata koji se svakodnevno dešavaju $i$ izazivaju ljudske žrtve i materijalnu štetu. Prirodne katastrofe, npr. poplave i erozija zemljišta u poslednjih par godina izazivaju ozbiljne probleme (Jovanović i dr., 2012; Jovanović, 2019).

Međutim, nije dovoljno samo sagledati probleme koje dovode do globalnog zagrevanja i promene klime, već se treba okrenuti ka prirodnim resursima kao što je šumski biodiverzitet, vršiti pošumljavanje, regulisati saobraćaj (Jovanović i dr., 2013; Jovanović, 2014).

U cilju očuvanja zdravlja važno je sačuvati sve resurse zbog proizvodnje zdrave i bezbedne hrane, usmeriti proizvodnju ka organskoj hrani (Jovanović, Širka, 2017).

Jedan od aspekata zaštite životne sredine predstavlja i jonizujuće zračenje, analiza radioaktivnosti, što je tema ovog rada.

Sistematsko ispitivanje radioaktivnosti u životnoj sredini se prema Zakonu o zaštiti od jonizujućeg zračenja i o nuklearnoj sigurnosti vrši radi utvrđivanja prisustva radionuklida u životnoj sredini i procene nivoa izlaganja stanovništva jonizujućim zračenjima $\mathrm{i}$ to $\mathrm{u}$ redovnim uslovima, u slučaju sumnje na akcident i toku akcidenta.

Brojna istraživanja radioaktivnosti u životnoj sredini ukazuju na to da postoji prisustvo radionuklida. Tako npr. rezultati analize zemljišta ukazuju na to da je zemljište bogat rezervoar radionuklida (Čučulović i dr., 2019).

U svim analiziranim uzorcima neobradivog zemljišta na teritoriji grada Beograda utvrđeno je prisustvo ${ }^{137} \mathrm{Cs}$. Visoka varijabilnost rezultata je posledica nehomogenosti depozicionih procesa posle černobiljskih akcidenata. Rezultati ovog istraživanja ukazuju da je i dalje neophodno stalno praćenje nivoa radioaktivnosti kako bi se procenila ugroženost životne sredine i prema potrebama omogućilo sprovođenje mera radijacione sigurnosti i bezbednosti (Janković-Mandić i dr., 2014).
Takodje, postoje rezultati radiološke analize uzoraka pepela nastalog sagorevanjem drveta koji potiče iz Srbije (Šešlak i dr., 2015). Rezultati analize prikazani u radu (Čučulović, Veselinović, 2015) ukazuju da je i posle dvadeset i sedam godina od akcidenta u Černobilju ${ }^{137} \mathrm{Cs}$ još uvek prisutan u gljivama Srbije.

$U$ drugoj polovini $X X$ veka započela su intenzivna istraživanja i epidemiološke studije o biološkim efektima nejonizujućeg zračenja (NIR). Paralelno sa ovim istraživanjima počeo je da raste $i$ interes javnosti za moguće zdravstvene rizike usled izlaganja veštačkim izvorima NIR, uslovljavajući, negativan stav javnog mnjenja (Vulević, Belić, 2012).

Što se tiče stanja kontaminacije radionuklidima u Republici Srbiji, treba istaći da se u životnoj sredini detektuje određena količina radionuklida, ali da naša zemlja ne pripada kategoriji kritičnog stanja kada je jonizujuće zračenje u pitanju. Detektovani radionuklidi u životnoj sredini su posledica nuklearne katastrofe u Černobilju 1986. godine i kontaminacija osiromašenim uranijumom 1999. godine usled NATO bombardovanja zemlje. Treba istaći da su potencijalni zagađivači životne sredine radionuklidima i nuklearne elektrane koje se nalaze $u$ susednim zemljama.

Sakupljanje i analizu uzoraka obavljaju pravna lica, koja obavljaju poslova zaštite od zračenja, a ovlašćena su od strane Agencije za zaštitu od jonizujućih zračenja i nuklearnu sigurnost Srbije (Agencija za zaštitu od jonizujućeg zračenja, 2017). $\mathrm{Na}$ osnovu dobijenog monitoringa radioaktivnosti, Agencija prati potencijalnu opasnost od jonizujućeg zračenja. Najveći deo zračenja koje primi prosečni stanovnik Srbije je od prirodnih izvora zračenja, Zemljine kore i kosmičkog zračenja.

$\mathrm{Na}$ osnovu detaljnih podataka institucija koje se bave monitoringom radioaktivnosti biće izneti podaci o stanju jonizujućeg zračenja u Republici Srbiji na osnovu merenja obavljenih u 2017. god.

\section{MATERIJALI I METODE / \\ MATERIALS AND METHODS}

$U$ našoj zemlji ovlašćene institucije koje se bave monitoringom radioaktivnosti su:

1. Institut za nuklearne nauke "Vinča", Laboratorija za zaštitu od zračenja i zaštitu životne sredine;

2. Laboratorija za ispitivanje uzoraka i doze jonizujućeg i nejonizujućeg zračenja, Prirodno-matematički fakultet, Novi Sad;

3. Institut za medicinu rada Srbije "Dr Dragomir Karajović“. 


\section{Merna mesta / Measurement locations}

Na teritoriji Republike Srbije imamo umreženih devet stanica: Novi Sad, Palić, Beograd, Vinča, Kladovo, Zlatibor, Niš, Vranje i Kosovska Mitrovica, u sklopu sistema pravovremene najave radijacionog ili nuklearnog akcidenta. Kontinuirano se meri detektorima jačina ekvivalentne doze gama zračenja u vazduhu, a podaci se sakupljaju na svakih pola sata. Dve od devet satnica poseduju jonizacione komore, a sedam Gajger-Milerov brojač.

Spoljašnje zračenje u vazduhu je u sklopu sistema za pravovremenu najavu akcidenta, meri se termoluminescentim (TL) dozimetrima. Očitavanje sa TL dozimetrima je na 3 meseca, a oni se postavljaju na visinu od 1 metar iznad nekultivisane travnate površine na 16 mernih mesta i to $u$ Beogradu, Vinči, Golupcu, Zaječaru, Lazarevcu, Kladovu, Kragujevcu, Novom Sadu, Nišu, Obrenovcu, Paliću, Pirotu, Prahovu, Sremskoj Mitrovici, Kraljevu i Užicu.

\section{Ispitivanje $i$ analiza sadržaja radionuklida $u$ vazduhu / Testing and analysis of radionuclide content in the air}

Uzorkovanje vazduha na sadržaj radionuklida obavlja se uz pomoć mernih stanica koje se nalaze u Beogradu (Zeleno Brdo), Vinči, Subotici (Palić), Nišu, Zlatiboru, Zaječaru i Vranju. Vazduh se uzorkuje na visini od jednog metra, pri čemu se uzorci sakupljaju kontinualno u toku 24 sata, svakog dana pomoću sistema za uzorkovanje vazduha. Protok vazduha je $u$ intervalu od $30-35 \mathrm{~m}^{3} / \mathrm{h}$, na mernoj stanici Palić $25 \mathrm{~m}^{3} / \mathrm{h}$. Vazduh se prosisava kroz filter papir efikasnosti $80 \%$ na slobodno nataloženu prašinu, na visini jedan metar iznad tla.

Sadržaj radionuklida određuje se u zbirnim mesečnim uzorcima vazduha, a mesečni uzorak određuje se srednjom vrednošću svih dnevnih uzoraka tokom meseca. Merenje se vrši germanijumskim detektorima visoke čvrstoće (HPGe) gamaspektrometrijskom analizom. Rezultati ispitivanja uzoraka vazduha izražavaju se u $\mathrm{Bq} / \mathrm{m}^{3}$.

\section{Ispitivanje $i$ analiza sadržaja radionuklida $u$ čvrstim i tečnim padavinama / \\ Testing and analysis of radionuclide content in solid and liquid precipitation}

Uzorci iz čvrstih i tečnih padavina prikupljaju se u svih devet mernih stanica, na taj način što se kontinuirano prikupljaju padavine tokom 24 sata, uz pomoć kolektora padavina postavljenih na visini od jednog metra iznad nekultivisane travnate površine.

Analiza uzorka dobija se mineralizacijom svih dnevnih uzoraka, koji se analiziraju spektrometrijom gama emitera. Rezultati ispitivanja uzoraka izražavaju se $\mathrm{u} \mathrm{Bq} / \mathrm{m}^{3}$.

\section{Ispitivanje i analiza sadržaja radionuklida u površinskim vodama i rečnom sedimentu / Testing and analysis of radionuclide content in surface water and river sediments}

Uzorkovanje površinskih voda vrši se svakodnevno iz Dunava kod Bezdana, Zemuna, Vinče i Prahova, Save kod Sremske Mitrovice i Beograda, Nišave kod Pirota, Tise kod Kanjiže, Timoka kod Knjaževca i Drine kod Loznice, a površinskih sedimenata sakupljaju se dva puta godišnje sa dna reka iz kojih se sakupljaju uzorci površinskih voda.

Sadržaj radionuklida emitera gama zračenja određena je metodom gamaspektrometrije u zbirnim mesečnim uzorcima rečne vode iz Dunava i Save, dok je u uzorcima rečne vode iz Nišave i Tise sadržaj radionuklida određen u zbirnim tromesečnim uzorcima. Metoda koja se primenjuje je precipitacija mangan(II)-oksidom, za ispitivanje sadržaja radionuklida iz velike zapremine analiziranog uzorka rečne vode. Ispitivan je sadrzaj ${ }^{3} \mathrm{H}$ i ${ }^{90} \mathrm{Sr}$ u zbirnom mesečnom uzorku površinske vode kod Bezdana i Save kod Sremske Mitrovice.

Radiohemijskom metodom koja se zasniva na izdvajanju stroncijuma iz uzorka oksalnom kiselinom određen je sadržaj ${ }^{90} \mathrm{Sr}$. Tricijum se određuje brzom metodom koja podrazumeva mešanje destilovanog uzorka sa scintilacionim koktelom i merenje aktivnosti tečnim scintilacionim detektorom.

Uzorci rečnog sedimenta su nakon uzorkovanja sušeni na temperaturi $105^{\circ} \mathrm{C}$ do konstantne mase. U uzorkovanju emitera gama zračenja primenjena je metoda gamaspektrometrije. U uzorcima sedimenta iz Dunava kod Bezdana i Save kod Sremske Mitrovice, pored emitera gama zračenja, određen je i sadržaj ${ }^{90} \mathrm{Sr}$. Sadržaj ${ }^{90} \mathrm{Sr}$ određen je nakon radiohemijskog izdvajanja stroncijuma iz analiziranog uzorka.

\section{Ispitivanje sadržaja radionuklida u vodi za piće / Testing radionuclide content in drinking water}

Uzorkovanje vode za piće vrši se iz gradskih vodovoda, koji snabdevaju više od 100.000 stanovnika. Uzorkovanje vode vrši se u Beogradu, Nišu, Novom Sadu, Kragujevcu, Čačku, Kraljevu i Leskovcu.

$U$ mesečnim uzorcima vode za piće vrši se zbirno određivanje ukupne alfa $i$ beta aktivnosti $i$ sadržaj radionuklida emitera gama zračenja. Pored ovih ispitivanja u zbirnim tromesečnim uzorcima vode za piće iz vodovoda koji se snabdevaju vodom iz Save i Dunava određuje se i sadržaj ${ }^{3} \mathrm{H}$ i ${ }^{90} \mathrm{Sr}$. Ukupna alfa i beta aktivnost izmerene su 
tečnim scintilacionim brojačem, standardom metodom ASTM D 7283-06 koja može da se primeni za određivanje koncentracije aktivnosti alfa emitera iznad $0,02 \mathrm{~Bq} / \mathrm{l}$ i beta emitera sa koncentracijom aktivnosti iznad 0,3 Bq/l. Sadržaj radionuklida emitera gama zračenja određen je metodom gamaspektrometrije u zbirnim mesečnim uzorcima.

Kada su u pitanju velike zapremine analiziranog uzorka rečne vode za prekoncentraciju radionuklida koristi se metoda precipitacije mangan(II)-oksalnom kiselinom. ${ }^{90} \mathrm{Sr}$ određen je radiohemijskom metodom koja se zasniva na izdvajanju stroncijuma iz uzorka oksalnom kiselinom. Tricijum se određuje brzom metodom koja podrazumeva mešanje destilovanog uzorka sa scintilacionim koktelom i merenje aktivnosti tečnim scintilacionim detektorom.

\section{Ispitivanje sadržaja radionuklida u životnim namirnicama i stočnoj hrani / Testing radionuclide content in foodstuffs and fodder}

Ispitivanje sadržaja radionuklida u životnim namirnicama obuhvataju uzorke mleka, mlečnih proizvoda, mesa, žitarica, povrća i voća, a stočna hrana uzorke sveže kabaste hrane, suve kabaste hrane i krmne smeše za ishranu različitih vrsta i kategorija životinja. Sakupljanje se vrši prema Pravilniku o utvrđivanju programa sistematskog ispitivanja radioaktivnosti (Agencija za zaštitu od jonizujućeg zračenja, 2018).

Uzorci životnih namirnica uzimaju se sa više različitih lokacija iz namirnica i mleka u Beogradu, Subotici, Novom Sadu, Nišu, Užicu (Zlatibor), Zaječaru i Vranju. Uzorci životnih namirnica uzimaju se iz primarne proizvodnje i sadržaj radionuklida ispituje se prema dozrevu vegetacije i uzgoju (za meso).

Uzorci mleka uzimaju se svakodnevno iz otkupne mreže mlekara, a analiziraju se zbirni mesečni uzorci iz svakog mesta posebno. Uzorci mlečnih proizvoda uzimaju se dva puta u toku godine.

Kompozitni mešani uzorci dečije hrane iz društvene ishrane (dečijih vrtića) uzimaju su tri puta u toku godine u Beogradu, Novom Sadu i Nišu.

Uzorci životnih namirnica ispituju se gamaspektrometrijski i određuje se sadržaj 90Sr. Rezultati merenja izražavaju se u Bq/l mleka i Bq/kg sveže hrane. Godišnje unošenje radionuklida u ljudski organizam izražava se u Bq/god., a odgovarajuća efektivna doza u mSv/god.

Ispitivanje sadržaja biološki značajnog fisionog radionuklida $137 \mathrm{Cs}$ u stočnoj hrani obuhvata svežu kabastu hranu, suvu kabastu hranu i krmne smeše za ishranu različitih vrsta i kategorija životinja. Uzorci stočne hrane za ispitivanje sadržaja radio- nuklida ${ }^{137} \mathrm{Cs}$ uzeti su iz primarne proizvodnje dva puta tokom godine.

Ispitivanje nivoa izlaganja jonizujućem zračenju prirodnog porekla u boravišnim prostorijama $i$ radnoj sredini / Testing the degree of exposure to natural ionizing radiation in living quarters and the workplace

Nivoi izlaganja jonizujućem zračenju u boravišnim prostorijama određeni su merenjem koncentracije radona ${ }^{222} \mathrm{Rn}$ u vazduhu. Merenja su obavljena u objektima starije gradnje kao i u novoizgrađenim objektima (stanovi, škole, vrtići) u Beogradu, Subotici, Novom Sadu, Nišu, Užicu, Zaječaru i Vranju. $\mathrm{Na}$ pomenutim lokacijama merenja se obavljaju jedanput godišnje i obuhvataju 71 objekat.

Merenja se vrše metodom apsorpcije radona na aktivnom uglju. Kanistri sa aktivnim ugljem su na mestu na kome se određuje koncentracija radona izlagani u preseku dva dana. Koncentracija radona određuje se na osnovu koncentracije njegovih kratkoživećih potomaka ${ }^{214} \mathrm{Bi}$ i ${ }^{214} \mathrm{~Pb}$ emitera gama zračenja.

\section{REZULTATI I DISKUSIJA / \\ RESULTS AND DISCUSSION}

\section{Rezultati analize sadržaja radionuklida u vazduhu / Analysis results of radionuclide content in the air}

Analizom je utvrđeno da se $u$ vazduhu nalaze prirodni i proizvedeni radionuklidi. Proizvedeni radionuklid ${ }^{137} \mathrm{Cs}$ najćešće je bio ispod granice detekcije, sem na Paliću gde je detektovan sa najvećom vrednošću $8,7 \times 10^{-6} \mathrm{~Bq} / \mathrm{m}^{3}$.

Maksimalna koncentracija ${ }^{106} \mathrm{Ru}$ detektovana je u mernoj stanici Beograd-Zeleno brdo $\left(48 \mathrm{mBq} / \mathrm{m}^{3}\right)$ u mesecu septembru. Pretpostavlja se da je ovaj radionuklid $u$ vazduhu dospeo ispuštanjem iz industrijskih i medicinskih objekata. Kosmogeni radionuklid ${ }^{7} \mathrm{Be}$ i prirodni radionuklid ${ }^{210} \mathrm{~Pb}$ imaju sezonski karakter. Vrednost koncentracije ${ }^{7} \mathrm{Be}$ u uzorcima vazduha je bila $u$ intervalu od $0,036 \mathrm{mBq} / \mathrm{m}^{3} \mathrm{u}$ oktobru $u$ mernoj stanici u Nišu, do $12,3 \mathrm{mBq} / \mathrm{m}^{3}$, u mesecu junu u mernoj stanici u Paliću. Sadržaj ${ }^{210} \mathrm{~Pb}$ je bio ispod granice detekcije, a najveća izmerena vrednost je bila $2,94 \mathrm{mBq} / \mathrm{m}^{3}$ u februaru u mernoj stanici Palić (Službeni glasnik RS, 76/2009).

\section{Rezultati analize sadržaja radionuklida $u$ čvrstim i tečnim padavinama / Analysis results of radionuclide content in solid and liquid precipitation}

Prisustvo veštačkog radionuklida ${ }^{127} \mathrm{Cs}$ detektovano je u veoma niskim koncentracijama ili ispod granice detekcije i kosmogenog radionuklida ${ }^{7} \mathrm{Be} s$ 
najvećom izmerenom vrednošću koncentracije 104 $\mathrm{Bq} / \mathrm{m}^{2}$, u decembru u mernoj stanici Vranje.

U septembru i oktobru detektovano je prisustvo proizvedenog radionuklida ${ }^{106} \mathrm{Ru}$. Maksimalna koncentracija detektovana je u oktobru na mernoj stanici Beograd-Zeleno brdo i to 2,6 Bq/ $\mathrm{m}^{2}$. Prisustvo ovog radionuklida u padavinama detektovano je u sličnim koncentracijama i na drugim lokacijama u Evropi.

Tabela 1 - Aktivnost ${ }^{106} \mathrm{Ru}\left(\mathrm{u} \mathrm{Bq} / \mathrm{m}^{2}\right)$ u uzorcima padavina tokom septembra i oktobra 2017. godine na ispitivanim lokacijama (Agencija za zaštitu od jonizujućeg zračenja, 2018)

Table 1 - ${ }^{106} \mathrm{Ru}$ activities (in $\mathrm{Bq} / \mathrm{m}^{2}$ ) in precipitation samples during September and October 2017 at analyzed locations (Agency for ionization radiation protection, 2018)

\begin{tabular}{|c|c|c|c|}
\hline \multirow{2}{*}{\multicolumn{2}{|c|}{$\frac{\text { Lokacija } \downarrow}{\text { Beograd }}$}} & Septembar & Oktobar \\
\hline & & $<0.3$ & $2.6 \pm 0.5$ \\
\hline \multicolumn{2}{|l|}{ Vinča } & $1.0 \pm 0.3$ & $<0.4$ \\
\hline \multicolumn{2}{|l|}{ Novi Sad } & $0.9 \pm 0.2$ & $0.48 \pm 0.09$ \\
\hline \multicolumn{2}{|l|}{ Subotica } & $<0.7$ & $<0.7$ \\
\hline \multicolumn{2}{|l|}{ Zlatibor } & $<0.7$ & $<0.7$ \\
\hline \multicolumn{2}{|l|}{ Kragujevac } & $<0.8$ & $<0.3$ \\
\hline \multicolumn{2}{|l|}{ Zaječar } & $<0.7$ & $<0.8$ \\
\hline \multicolumn{2}{|l|}{ Niš } & $<1$ & $<0.3$ \\
\hline \multicolumn{2}{|l|}{ Vranje } & $<0.2$ & $<0.2$ \\
\hline
\end{tabular}

Distribucija tricijuma u uzorcima padavina prikupljenim na referentnoj metereološkoj stanici Zeleno brdo u Beogradu ukazuje na normalne sezonske varijacije sa izraženim letnjim maksimumom i minimumom u zimskim mesecima (Janković i dr., 2016).

\section{Rezultati analize sadržaja radionuklida $u$ površinskim vodama i rečnom sedimentu / Analysis results of radionuclide content in surface water and river sediments}

Najveći deo detektovane aktivnosti gama emitera potiče od prirodnih radionuklida, dok su aktivnosti veštačkog radionuklida ${ }^{137} \mathrm{Cs}$ bile ispod granice detekcije u svim uzorcima rečne vode ili blisko granici detekcije $0,027 \pm 0,011 \mathrm{~Bq} / \mathrm{l}$ u uzorku vode reke Tise za period april-juni.

Koncentracije radionuklida u uzorcima rečnih površinskih voda su ispod izvedenih koncentracija u vodi za piće. Rezultati određivanja tricijuma i stroncijuma u zbirnim mesečnim uzorcima su ispod granica detekcije navedenih u Pravilniku o granicama sadržaja radionuklida u vodi za piće, životnim namirnicama, stočnoj hrani, lekovima, predmetima opšte upotrebe, građevinskom materijalu i drugoj robi koja se stavlja u promet (Službeni glasnik RS, 36/2018).

Detektovanje radionuklida ${ }^{137} \mathrm{Cs}$ u rečnim sedimentima je veštačkog porekla. ${ }^{137} \mathrm{Cs}$ se kreće od $0,39 \mathrm{~Bq} / \mathrm{kg}$ do $16,1 \mathrm{~Bq} / \mathrm{kg}$. Aktivnost ${ }^{137} \mathrm{Cs}$, potiče od preostale kontaminacije prouzrokovane nuklearnim akcidentom u Černobilju 1986. godine.

Prirodni radionuklidi u uzorcima rečnog sedimenta su u granicama uobičajenih vrednosti za sediment $i$ zemljište našeg regiona. Maksimalne vrednosti specifičnih aktivnosti prirodnih radionuklida su izmerene u uzorku rečnog sedimenta reke Dunav kod Zemuna.

\section{Rezultati analize sadržaja radionuklida u vodi za piće / Analysis results of radionuclide content in drinking water}

U vodama za piće u 2017. godini u sedam gradova u Srbiji izmerene koncentracije ukupne alfa i beta aktivnosti su daleko ispod referentnih vrednosti za vodu za piće i to $0,1 \mathrm{~Bq} / \mathrm{l}$ za ukupnu alfa aktivnost i $1 \mathrm{~Bq} / \mathrm{l}$ za ukupnu beta aktivnost.

Sadržaj tricijuma ${ }^{3} \mathrm{H}$ i stroncijuma ${ }^{90} \mathrm{Sr} \mathrm{u}$ ispitivanim uzorcima vode je ispod granice detekcije.

Rezultati gamaspektrometrijske analize su ukazali na prisustvo prirodnih radionuklida ( ${ }^{226} \mathrm{Ra},{ }^{232} \mathrm{Th}$ ) u veoma niskim koncentracijama i znatno ispod vrednosti izvedenih koncentracija. Prisustvo veštačkog radionuklida ${ }^{137} \mathrm{Cs}$ nije ustanovljeno.

\section{Rezultati analize sadržaja radionuklida u životnim namirnicama i stočnoj hrani / Analysis results of radionuclide content in foodstuffs and fodder}

Specifična aktivnost ${ }^{137} \mathrm{Cs}$ u mleku je bila ispod granica detekcije za uzorke iz svih gradova, osim za uzorke mleka iz Užica gde je izmerena aktivnost ${ }^{137} \mathrm{Cs}$ znatno niža od izvedenih koncentracija. U svim uzorcima mleka su bile merljive specifične aktivnosti ${ }^{90} \mathrm{Sr}$, takođe, veoma niske u poređenju sa izvedenim koncentracijama.

Izmerene koncentracije radionuklida $u$ mleku su daleko ispod granice sadržaja od $15 \mathrm{~Bq} / \mathrm{l}$ za ${ }^{137} \mathrm{Cs}$ i $64 \mathrm{~Bq} / \mathrm{l}$ za ${ }^{90} \mathrm{Sr}$. Gamaspektrometrijskom analizom u namirnicama iz prehrambenih kombinata $\mathrm{i}$ individualne proizvodnje pokazuju značajno niske nivoe aktivnosti ${ }^{137} \mathrm{Cs}$ i ${ }^{90} \mathrm{Sr} u$ uzorcima povrća, voća, žitarica, mesa i mlečnih proizvoda i uglavnom su ispod vrednosti od $1 \mathrm{~Bq} / \mathrm{kg}$. Detekcija ${ }^{137} \mathrm{Cs}$ i ${ }^{90} \mathrm{Sr}$ su posledica akcidenta u Černobilju 1986. godine. Na osnovu sadržaja ${ }^{137} \mathrm{Cs}$ i ${ }^{90} \mathrm{Sr}$ u životnim namirnicama i na osnovu podataka Republičkog zavoda za statistiku za 2013. godinu o godišnjoj potrošnji namirnica procenjeno je da je efektivna 
doza koja potiče od unosa ${ }^{137} \mathrm{Cs}$ i ${ }^{90} \mathrm{Sr}$ ingestijom manja od 0,01 mSv.

Određivanje sadržaja radionuklida u uzorcima hrane za životinje je pokazalo veoma niske zanemarljive aktivnosti proizvedenog ${ }^{137} \mathrm{Cs}$ i kosmogenog radionuklida ${ }^{7} \mathrm{Be}$.

\section{Rezultati analize nivoa izlaganja jonizujućem zračenju prirodnog porekla u boravišnim prostorijama i radnoj sredini / \\ Analysis results of the degree of exposure to natural ionizing radiation in living quarters and the workplace}

Koncentracije aktivnosti radona u boravišnim prostorijama i radnim sredinama (vrtići i škole) su ispod interventnog nivoa za postojeće objekte prema našoj regulativi. Interventni nivoi za hronično izlaganje radonu u stanovima jednaki su godišnjoj prosečnoj koncentraciji od $200 \mathrm{~Bq} / \mathrm{m}^{3}{ }^{222} \mathrm{Rn}$ u vazduhu u novoizgrađenim stambenim objektima, a $400 \mathrm{~Bq} / \mathrm{m}^{3}{ }^{227} \mathrm{Rn}$ u vazduhu za postojeće stambene objekte i evropske preporuke od $300 \mathrm{~B} \mathrm{kq} / \mathrm{m}^{3} \mathrm{za}$ boravišne i radne prostorije.

\section{ZAKLJUČAK / CONCLUSION}

Rezultati Agencije za zaštitu od jonizujućeg zračenja Republike Srbije govore o tome da se naša zemlja ne nalazi u kritičnoj kategoriji. Vrednosti prirodnih radionuklida $i$ veštačkih dugoživećih radionuklida su u veoma niskim granicama, jedva u granicama detekcije. Ta detektovana koncentracija radionuklida u životnoj sredini uglavnom je od černobiljskih padavina. Sve izmerene vrednosti su dostupne javnosti.

Određena proizvodna postrojenja mogu biti kontaminatori životne sredine radionuklidima, kao npr. nuklearne elektrane u okruženju Republike Srbije. Na udaljenosti $1000 \mathrm{~km}$ od njene granice, nalazi se 21 nuklearna elektrana sa 44 reaktora, od čega je šest nuklearnih elektrana sa 12 reaktora udaljeno $500 \mathrm{~km}$ od granice naše države. Samo na Dunavu ih je 10, koji takođe mogu biti potencijalni zagađivači. Iz tog razloga je neophodno pratiti radioaktivnost, ugroženost životne sredine u slučaju povećanja radijacije, kao i sprovođenje mera zaštite od radioaktivnog zračenja. Neophodno je da javnost bude informisana o svim osobinama jonizujućeg zračenja, mogućim negativnim posledicama $\mathrm{i}$ tačnim informacijama o intenzitetu zračenja izmerenim u monitoring centru i uticaju na životnu sredinu.

Analiza podataka koji se tiču kontrolisane prakse izlaganja za stanovništvo iznosi $1 \mathrm{mSv}$ godišnje. $\mathrm{Na}$ osnovu rezultata merenja, doze radionuklida koje prosečan stanovnik unese ingestijom ili inha- lacijom je vrednost $0,01 \mathrm{mSv}$, što je zanemarljiva vrednost jer ne može izazvati posledice po zdravlje.

Neophodna je edukacija stanovništva po pitanju zračenja sa posebnom pažnjom na jonizujuće zračenje i odvajanje određenih sredstava na nivou države u cilju zaštite od uzroka nastanka zračenja, kao i njegovih posledica po živi svet i zdravlje ljudi.

\section{LITERATURA / REFERENCES}

[1] Agencija za zaštitu od jonizujućeg zračenja i nuklearnu sigurnost Srbije, Godišnji izveštaj za monitoring, jul 2017.

[2] Agencija za zaštitu od jonizujućih zračenja i nuklearnu sigurnost Srbije, Godišnji izveštaj za monitoring, jul 2018.

[3] Brkić, D., Jovanović, O., Radosavljević, D., Petrović, J., Stamenović, M. (2012). Potencijal energije vetra u Srbiji, Zbornik radova 7 . Simpozijum „Reciklažne tehnologije $i$ održivi razvo", Soko Banja, 539-549.

[4] Čučulović, A., Veselinović, D. (2015). Nivoi aktivnosti ${ }^{137} \mathrm{Cs}$ u gljivama Srbije u periodu od 1999-2013, Ecologica, 22 (79), 484-487.

[5] Čučulović, A., Stanojković, J., Čučulović, R., Nestorović, S., Radaković, N., Veselinović, D. (2019). Nivo aktivnosti ${ }^{137} \mathrm{Cs}$ i ${ }^{40} \mathrm{~K}$ u zemljištu sakupljenom 2018. godine u NP Đerdap, Ecologica, 26 (94), 136-139.

[6] Janković-Mandić, Lj., Petrović, J., Ćajić, M., Dragović, R., Đorđević, M., Nikolić, M., Dragović, S. (2014). Sadržaj ${ }^{137}$ Cs u zemljištu Beograda i procena jačine doze ovog radionuklida, Ecologica, 21 (76), 800-803.

[7] Janković, M., Todorović, N., Stojković, I., Sarap, N.,Todorović, D. (2016). Sadržaj tricijuma u padavinama u Beogradu, Ecologica, 23 (81), 19-22.

[8] Jovanović, O., Stamenović, M., Petrović, J. (2012). Opšte opasnosti od hemijskih akcidenata, Ecologica, 19 (66), 258-263.

[9] Jovanović, O, Stamenović, M., Petrović, J. (2012a). Mogućnost korišćenja obnovljivih izvora energije u Srbiji, Ecologica, 19 (67), 535-540.

[10] Jovanović, O., Stamenović, M., Petrović, J. (2013). Uticaj globalnog zagrevanja na klimu u Srbiji, Ecologica, 20 (69), 79-83.

[11] Jovanović, O., Žarković, D., Romčević, J. (2013a). Potencijal sunčeve energije u Srbiji, Ecologica, 20 (70), 261-266.

[12] Jovanović, O., Žarković, D., Baltić, J. (2013b). Mogućnost korišćenja geotermalnih izvora u Srbiji, Ecologica, 20 (72), 731-735. 
[13] Jovanović, O. (2014). Održivost šumskog diverziteta, Ecologica, 21 (76), 689-696.

[14] Jovanović, O., Širka, D. (2017). Budućnost organske poljoprivrede, Ecologica, 24 (88), 833-837, 2017.

[15] Jovanović., O. (2019). Problemi erozije i poplava na području Srbije, Ecologica, 26 (94), 259263, 2019.

[16] Službeni glasnik RS, broj 76/2009 (https://www.slglasnik.com/)
[17] Službeni glasnik RS, br. 36/2018, str.11 (https://www.slglasnik.com/)

[18] Šešlak, B., Ujić, P., Vukanac, I., Kandić, A., Đurašević, M., Čeliković, I., Milošević, Z. (2015). Sadržaj ${ }^{137} \mathrm{Cs}$ i ${ }^{40} \mathrm{~K}$ u pepelu drveta, Ecologica, 22 (80), 605-608.

[19] Vulević, V., Belić, Č. (2012). Određivanje nivoa radiofrekvencijskog zračenja u životnoj sredini, Ecologica, 19 (67), 497-500. 